\title{
Orthodoxy, Heresy and Treason in Elizabethan England
}

Orthodoxie, hérésie et trahison dans l'Angleterre élisabéthaine

\section{Claire Cross}

\section{OpenEdition \\ 1 Journals}

\section{Electronic version}

URL: http://journals.openedition.org/rfcb/3561

DOI: $10.4000 /$ rfcb.3561

ISSN: 2429-4373

\section{Publisher}

CRECIB - Centre de recherche et d'études en civilisation britannique

\section{Printed version}

Date of publication: 1 March 2013

ISBN: 2-911580-37-0

ISSN: 0248-9015

\section{Electronic reference}

Claire Cross, "Orthodoxy, Heresy and Treason in Elizabethan England », Revue Française de Civilisation Britannique [Online], XVIII-1 | 2013, Online since 01 March 2013, connection on 20 March 2020. URL : http://journals.openedition.org/rfcb/3561 ; DOI : https://doi.org/10.4000/rfcb.3561

This text was automatically generated on 20 March 2020 .

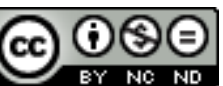

Revue française de civilisation britannique est mis à disposition selon les termes de la licence Creative Commons Attribution - Pas d'Utilisation Commerciale - Pas de Modification 4.0 International. 


\title{
Orthodoxy, Heresy and Treason in Elizabethan England
}

\author{
Orthodoxie, hérésie et trahison dans l'Angleterre élisabéthaine
}

\author{
Claire Cross
}

1 Despite the severe penalties laid down in the Acts of Supremacy and Uniformity of 1559, the Elizabethan Government initially displayed great unwillingness to proceed against Catholics for their religious beliefs, but changed its stance on the promulgation of the papal bull of 1570 which excommunicated the queen and released her subjects from their allegiance. At the beginning of the reign, Protestant and Catholic controversialists in their publications concentrated upon whether the English Church could be considered to be a true Church; after the State began prosecuting seminary priests and their lay protectors for treason, the debate moved on to whether Catholics were being put to death exclusively for a political crime or sacrificing their lives solely for their faith. The irreconcilable positions of the two sides concerning orthodoxy, heresy, and treason form the subject of this essay.

\section{Prosecuting for heresy}

Unlike France where the Albigensians had presented a very serious danger to the Catholic Church in the High Middle Ages, England had not experienced a major outbreak of heresy before the emergence of Lollardy in the second half of the fourteenth century. To counter this threat, in 1401, the Government had found it necessary to devise a new law, De heretico comburendo, under which heretics condemned by the Church could be handed over for execution to the secular power, and burnings of relapsed heretics had occurred with some regularity from this date. Lollardy seems to have revived at the beginning of the sixteenth century and Lollards were still being put to death under the provisions of the act in the first part of the reign of Henry VIII. When, therefore, heretical ideas began penetrating England from the continent after 1517, the king's ministers automatically employed this legislation against those attracted to the new learning, and clerics like Thomas Bilney, a Catholic reformer, who 
seems to have held entirely orthodox views on the sacrament of the altar, and out-andout Lutheran converts such as Richard Bayfield and John Frith all perished at the stake in the early 1530s. After something of a respite during the Cromwellian regime, six religious deviants died on a single day in July 1540, the Government, in a distinction which foreshadowed that drawn in subsequent reigns, sentencing the three Evangelicals, Robert Barnes, Thomas Garrard and William Jerome, who had offended against the current religious orthodoxy, to be burnt for heresy, and the three Catholics, Thomas Abell, Edward Powell and Richard Fetherstone, who had refused to acknowledge the royal supremacy, to be executed for treason. ${ }^{1}$

3 The religious conservatives, who had seemed to be gaining the upper hand in the last years of Henry VIII, suffered an abrupt change of fortune on the accession of the boy king Edward VI on 28 January 1547. Almost immediately the reformers seized control of the Council, and the first Parliament of the reign repealed all the heresy laws. The government imprisoned its most implacable Catholic opponents like Stephen Gardiner and deprived them of their offices in both Church and State, but for five and a half years, with the sole exception of the Anabaptist, Joan Butcher, deemed as much a social as a religious radical, no one went to the stake on account of religion.

4 After the failure of Edward VI to secure the future of Protestantism by diverting the succession to Lady Jane Grey, the accession of Mary Tudor in July 1553 brought the lull in persecution to an end. Having herself never deviated from Catholic orthodoxy, the new queen saw the restoration of the old religion and the reconciliation of the nation to Rome as her main mission in life. By Christmas 1553, the Latin mass and all the other Catholic offices had replaced the English services from the second Edwardian Book of Common Prayer, which in any case had been in use for less than a year. While apparently ready to accept the change in worship, the laity proved much more resistant to the Government's determination to bring back the old heresy laws, and it was not until the third Parliament of the reign that the Lords and the Commons finally agreed to their revival. The laws came into operation at the end of January 1555, and on 4 February, John Rogers, a London minister and biblical scholar, was burnt at Smithfield. In the three and a half years between February 1555 and the queen's death on 17 November 1558 , in a concerted campaign to eliminate heresy by force, which the most recent historian of the Marian Church has described as 'the most intense religious persecution of its kind anywhere in sixteenth-century Europe', around 283 Protestants perished at the stake and some thirty more died in prison. At first, with the intention of driving home the consequences of heresy, the authorities held the burnings in public in London and other major towns, but later, because of popular disturbances, particularly at Smithfield, the bishop of London, Edmund Bonner, arranged for them to take place at unsocial hours in less populous locations. In addition to the majority of the leaders of the Edwardian Church who had remained in the country, the ranks of the martyrs also included a contingent of quite humble lay men and women. More influential members of the laity, who had supported Protestantism in the previous reign, seem to have used their social connections to evade detection. ${ }^{2}$

5 From the very beginning of Mary's reign, her councillors had encouraged the departure of the foreign theologians and their students whom Cranmer had attracted to the two English universities, and in the following months and years, more and more English Protestants followed in their wake. Between the summer of 1553 and the autumn of 1558, approaching 800 English Protestants, men, women, children and servants fled to 
the continent: of this total, a quarter were clergy or university students preparing to enter the ministry, and another quarter, gentlemen, merchants and members of the professions. The exiles kept in close touch with their brethren in England, and John Foxe in particular took it upon himself to collect first-hand reports of their sufferings. He published his Latin account of the heresy trials and burnings, Rerum in ecclesia gestarum [...] commentarii, in August 1559, and a much augmented English version, the immensely influential Actes and Monuments, popularly known as The Book of Martyrs, in the spring of $1563 .^{3}$

\section{Defining the true Church}

In many respects, the existence of an English Protestant Church in embryo on the continent together with the persuasive nature of English Protestant propaganda determined the future of religion in England after Mary's death. Resolved to avoid the cruelty of the previous regime, Elizabeth's advisors seem at first to have hoped that Mary's leading ecclesiastics would behave as their Henrician predecessors had done and submit to the superior might of the State. Events, however, played very differently the second time round. On the calling of the first Parliament of the reign in January 1559, the Marian bishops mounted a spirited defence of the mass and the papacy, but failed to prevent the passage just after Easter of bills restoring the royal supremacy and re-imposing a Protestant form of worship. The Act of Supremacy, which required all ecclesiastical and secular officeholders to acknowledge the Crown as the Supreme Governor of the English Church, provided that any person who rejected the oath for the third time could be judged guilty of high treason. In contrast to the 1530s, when all but one of the bishops, John Fisher, had abandoned the pope and recognised the king as the Head of the English Church, the entire Marian episcopate, with only one exception, together with a substantial number of the higher clergy, refused to swear the oath and lost their offices. Since so many of the Edwardian bishops had perished in the Marian burnings, the Crown had little alternative but to turn to the newly returned Protestant exiles to fill the vacant positions. ${ }^{4}$

With the intention of preventing any future persecution of Protestants, the Act of Supremacy had limited heresy to that considered 'to be heresy by the authority of the canonical scriptures, or by the first four general councils'. This definition lay behind the challenge made in November 1559 by John Jewel, the bishop elect of Salisbury, to his Catholic adversaries that if any of them were able "to bring any one sufficient sentence out of any old doctor or father, or out of any general council, or out of the holy scripture, or any one example out of the primitive Church for the space of six hundred years after Christ' in support of the current teachings and practices of the Roman Church, he then 'would give over and subscribe to them.' The ensuing literary controversy led directly to Jewel's celebrated defence of the Church of England against charges of heresy, Apologia pro ecclesia Anglicana, published first in Latin in January 1562, and then in an English translation two years later. In his Apology, Jewel attempted both to uphold the reformed doctrine of the English Church, and to refute accusations that it had departed from the true Church by asserting that, on the contrary, it had returned to 'the primitive Church of the ancient fathers and apostles'. ${ }^{5}$

In a mirror image of the previous reign, the Elizabethan religious settlement precipitated an exodus to the continent of Catholic intellectuals from the two English 
universities, most particularly from Oxford. A group of these scholars established an alternative English college at Douai in the Low Countries, and from there, in 1564, Thomas Harding produced An Answere to Maister Juelles Chalenge, which he followed a year later with a paragraph by paragraph Confutation of a booke intituled 'An apologie of the Church of England'. Both antagonists attracted an army of literary supporters trying to prove that their Church was the true heir of the early Church, and the debate raged on until Jewel's death in 1571, by which time the Catholic exiles had switched their attention to even more pressing concerns. ${ }^{6}$

\section{Prosecuting for treason or religion}

9 After they had been deprived of their livings, the Elizabethan Government had treated Catholic clergy relatively leniently. By deliberately not posing the oath of supremacy for a third time, it had avoided trying recusants for treason, and the worst penalty they had had to face in the first decade of the reign was imprisonment and house arrest. This state of affairs came to an end in May 1568 when the deposed Mary Queen of Scots fled across the Scottish border into Cumberland, and for the first time in a decade, English Catholics had a plausible Catholic claimant to the throne around whom to rally. At almost exactly the same date, William Allen began transforming Douai into a seminary for the training of a new generation of English Catholic priests for the mission to England. Financed by subsidies from Spain and the papacy, the college expanded rapidly and, by 1577, had over a hundred English students preparing for the priesthood. ${ }^{7}$

10 While the causes of the rebellion which erupted in the north of England in the autumn of 1569 seem to have been as much political as religious, the earls of Northumberland, Cumberland and Westmorland certainly made use of religion to justify their insurrection, restoring the mass in Durham cathedral at the height of the revolt. They soon dispersed when faced with superior Government forces, but before the news of their defeat reached Rome, Pius V intervened on behalf of the rebels. Having first declared in his bull of January 1570 how 'the servant of vice, Elizabeth, pretended queen of England' had 'acquired the kingdom, and outrageously usurped for herself the place of supreme head of the Church in all England', he went on to pronounce 'the aforesaid Elizabeth to be heretic and an abetter of heretics', and 'to have incurred the sentence of excommunication', before depriving her 'of her pretended claim to the aforesaid kingdom and of all lordship, dignity and privilege whatsoever' and absolving her subjects from their allegiance. Until the revolt of the earls, most English Catholics had professed their loyalty to the pope in spiritual matters and to their secular sovereign in matters of state, but now, though many still attempted to maintain this distinction, the papal bull made this logically impossible, and for Protestants set in stone the connection between Catholicism and treason. ${ }^{8}$

11 Only four years after Elizabeth's excommunication, the first four seminary priests left Douai on the mission to return England to the Catholic faith. In contrast to the Marian authorities who had burnt Protestants as heretics under the provisions of the statute of De heretico comburendo, because of the papal bull, the Elizabethan Government could with some justification claim that these priests had entered the country to seduce the queen's subjects from their allegiance, and on their prosecution and conviction for treason in the common law courts insisted upon their enduring the death reserved for 
traitors. Between 1577 and the end of the reign, just over 200 Catholics, largely though not exclusively priests, were hung, drawn and quartered. ${ }^{9}$

As soon as he had taken control of the college at Douai, if not before, William Allen had concluded that the reconversion of England could only be achieved by Elizabeth's removal, and for the next two decades, he masterminded a succession of plots for the invasion of the country by France or Spain. He took pains, however, to conceal all knowledge of his plans from the priests in training, who were forbidden from discussing politics and commanded to concentrate exclusively on the winning of souls while on the English mission. Consequently, during the trial of Edmund Campion in 1581, the Government found it extremely difficult to prove that by ministering to the spiritual needs of English Catholics, he had committed treason as defined under the statute of 1352. To close this loophole, Parliament in 1581 passed a new act 'to retain the queen's majesty's subjects in their due obedience' making it treasonable for a priest to persuade an English subject to profess allegiance to the pope. A further law of 1584, which banished all seminary priests and Jesuits from the country within forty days, provided that those who defied the order or entered the country in the future should also be deemed guilty of high treason. ${ }^{10}$

Within months of Campion's death, the Catholic publisher Richard Verstegan brought out a description of his martyrdom, following it in successive years with further accounts of the English heretics' cruelty towards priests. In an attempt to counter these charges and convince continental powers that, faced with the same threat to their national security, they would have acted in exactly the same way as the English Government had done, in December 1583, the queen's chief minister William Cecil, Lord Burghley, produced The Execution of Justice in England. He began by stating that the pope had outrageously intervened in English internal affairs not only by proclaiming 'her majesty, being the lawful queen and God's anointed servant, not to be the queen of the realm' and commanding 'upon pains of excommunication, [...] all her subjects to depart from their natural allegiances', but also by allowing the establishment of seminaries with the sole purpose of training for the priesthood 'persons disposed naturally to sedition [...] secretly to persuade the people to allow of the pope's foresaid bulls and warrants and of his absolute authority over all princes and countries.' Yet none of 'these seditious seedmen and sowers of rebellion', he maintained, had been 'dealt withal upon questions of religion, but justly by order of laws, openly condemned as traitors. ${ }^{11}$

14 Again and again, Cecil hammered home the argument that his Government had not embarked on a religious persecution:

And though there are many subjects known in the realm that differ in some opinions of religion from the Church of England and that do also not forbear to profess the same, yet in that they do also profess loyalty and obedience to her majesty and offer readily in her majesty's defense to impugn and resist any foreign force, though it should come or be procured from the pope himself, none of these sort are for their contrary opinions in religion prosecuted or charged with any crimes or pains of treason, nor yet willingly searched in their consciences for their contrary opinions that savor not of treason..$^{12}$

15 He furthermore compared the rebellious seminary priests with the loyal Marian Protestants, most of whom 'had never by the sacrament of baptism or by confirmation, professed, or [were] ever taught or instructed, or ever had heard of any other kind of religion, but only of that which by their blood and death in the fire they did as true martyrs testify.' Despite all their tribulations, 'yet they never at their death denied their lawful queen, nor 
maintained any of her open and foreign enemies, nor procured any rebellion or civil war, nor did sow any sedition in secret corners, nor withdrew any subjects from their obedience, as these sworn servants of the pope have continually done. ${ }^{13}$

These so called 'unarmed scholars and priests', therefore, should be seen as what they really were, wolves in sheep's clothing. 'Their secret teachings and reconciliations' have no other purpose but 'by rebellion to shed the blood of all her faithful subjects. The rewards of the invaders (if they could prevail) should be the disinheriting of all the nobility, the clergy, and the whole commonalty that would [...] defend their natural gracious queen, their native country, their wives, their children, their family and their houses. ${ }^{14}$

Within months of the appearance of Cecil's treatise, William Allen responded with $A$ True, Sincere, and Modest Defense of English Catholics. While spending much of his time denying Cecil's assertions and contending that the sole object of the mission to England had been to win back the nation to the Catholic faith, and that the state had been persecuting the seminary priests exclusively on account of their religious beliefs, he did not shy away from confronting the issues of orthodoxy and heresy, which Cecil had been eager to avoid. Allen considered states were answerable to God for their subjects' souls as well as their bodies. The Marian Government had fully recognised this responsibility, and striven to inculcate right belief. The present Government, in contrast, by not defining heresy correctly and by not prosecuting religious deviants, had scandalously failed to fulfill its obligations:

You profess to put none to death for religion. You have no laws to put any man to death for his faith. You have purposely repealed by a special statute made in the first year and parliament of this queen's reign all former laws of the realm for burning heretics, which smelleth of something that I need not here express. You have provided at the same time that nothing shall be deemed or adjudged heresy but by your parliament and convocation. You have not yet set down by any new law what is heresy or who is an heretic. Therefore you can neither adjudge of our doctrine as of heresy nor of us as of heretics. Nor have you any law left whereby to execute us. And so, to put any of us to death for religion is against justice, law, and your own profession and doctrine. ${ }^{15}$

The situation had been entirely different in the previous reign, when the Government had rightfully prosecuted for heresy:

Queen Mary against the Protestants executed only the old laws of our country and of all Christendom made for punishment of heretics, by the canons and determination of all popes, councils, Churches and ecclesiastical tribunals of the world, allowed also and authorised by the civil and imperial laws and received by all kingdoms Christian besides. And who then hath any cause justly to be grieved? Why should any man complain or think strange for executing the laws which are as ancient, as general and as godly against heretics as they are for the punishment of traitors, murderers or thieves? ${ }^{16}$

19 In his Defense of English Catholics, Allen was battling for the very lives of the seminary priests and prepared to use every available weapon in his armory on their behalf, but in asserting that no priests had been involved in secular politics, as his most recent biographer has conceded, he was being somewhat 'economical with the truth'. While prohibited from discussing matters of state under the present dispensation, had a Catholic power succeeded in invading the kingdom, the priests would have become the prime instruments in effecting a counter-reformation. Even at this stage, when he was still concealing his own involvement with England's enemies, Allen made no attempt to hide his support of the imposition of orthodoxy by force: 
There is no war in the world so just or honorable, be it civil or foreign, as that which is waged for religion; we say for the true, ancient, catholic, Roman religion; which by the laws of Holy Church and all Christian nations is adjudged to be the only true worship of God and unto the obedience of which all princes and people have yielded themselves, either by oath, vow, or sacraments, or every of these ways. and all ecclesiastical admonition and censure, which is the high priest's and Church's most proper weapon and is more to be feared of all faithful persons (as holy St Augustine saith) "than to be hewed in pieces with the sword, burned with the fire, or torn in sunder of wild beasts." 17

As in the earlier controversy between Jewel and Harding, there could be no squaring of the circle, and neither Cecil nor Allen emerged as more than polemicists in this most acrimonious of literary battles. They wrote at a time when England was drifting into a war with Spain, the country was gripped with anti-Catholic hysteria, and Protestants were flocking to join the bond of association to ensure no Catholic candidate could profit from any accident befalling Elizabeth. In 1587, the very year in which Mary Queen of Scots was executed for treason for conspiring against the English Crown, Allen revealed his true colours by publicly defending Sir William Stanley's surrender of Deventer to the army of Philip II. A few months later in his Admonition to the Nobility and People of England, published to coincide with the sailing of the Spanish Armada, he gave English Catholics the signal to rise up and overthrow the queen. ${ }^{18}$

Despite the failure of the Armada in 1588 and subsequent invasion attempts in the following decade, Elizabethan Protestants never lost their fear that the nation might be re-converted to Catholicism by force and continued to regard Jesuits and seminary priests as emissaries of Spain. Although there was no obvious Catholic candidate for the English throne after the execution of Mary Queen of Scots, Allen and then, after his death in 1594, the Jesuit Robert Persons gave substance to these concerns by advancing the claims of a Spanish princess. In the event, the Protestant James VI of Scotland succeeded Elizabeth with remarkably little resistance in March 1603, continental Catholic powers made no attempt to interfere in English internal affairs, and the new century might well have seen some sort of accommodation between the English Catholic community and the rest of the political nation, had not a little band of Catholic terrorists tried to bring about the restoration of Catholicism by blowing up the Protestant monarch, lords and commons assembled in Westminster for the opening of Parliament on 5 November 1605.

\section{Conclusion}

Although Richard Hooker could still assert at the end of Elizabeth's reign that 'there is not any man of the Church of England but the same is also a member of the commonwealth; nor any member of the commonwealth, which is not also of the Church of England', the English Church and State had never in fact been coterminous since Henry VIII's break with Rome. While Mary I and her ministers had gone to the ultimate extreme of burning Protestants for heresy and their Elizabethan counterparts had retaliated by executing Catholics for treason, neither had succeeded in reducing the country to a uniformity in religion. Yet despite, or perhaps because of, the unpalatable political reality, the arguments put forward by Tudor Protestant and Catholic polemicists continued for 
centuries to attract those who still dreamt the impossible dream of recreating in England a Church which once more comprehended all the subjects of state. ${ }^{19}$

\section{NOTES}

1. Lucien CARRIVE, "Le Statut pénal de l'hérésie en Angleterre au dix-septième siècle ", in Christiane d'HAUSSY (ed.), Orthodoxie et hérésie, Paris : Didier-Érudition, 1993, pp. 25-37.

2. Eamon DUFFY, Fires of Faith: Catholic England under Mary Tudor, New Haven \& London: Yale University Press, 2009, pp. 7, 79, 89, 160.

3. Ibid., pp. 1-28; Christina H. GARRET, The Marian Exiles: A Study in the Origins of Elizabethan Puritanism, Cambridge [1938]: Cambridge University Press, 1966, pp. 32, 41; Thomas S. FREEMAN, 'Foxe, John (1516/17-1587), martyrologist', in H. C. G. MATTHEW \& Brian HARRISON (eds.), Oxford Dictionary of National Biography, Oxford: Oxford University Press, 2004, vol. 20, pp. 695-709 [subsequently ODNB].

4. J. E. NEALE, Elizabeth I and her Parliaments, 1559-1581, London: Jonathan Cape, 1953, pp. 33-84.

5. Statutes of the Realm, London: George Eyre \& Andrew Strahan, 1810-1828, IV, part I, pp. 350-355; John CRAIG, 'Jewel, John (1522-1571), bishop of Salisbury', in ODNB, vol. 30, pp. 108-113.

6. CRAIG, Ibid.; L. E. C. WOODING, 'Harding, Thomas (1516-1572), theologian and religious controversialist', in ODNB, vol. 25 pp. 172-173.

7. Arnold O. MEYER, England and the Catholic Church under Queen Elizabeth [1916], London: Kegan Paul, 1967, pp. 9-50; Eamon DUFFY, 'Allen, William (1532-1594), cardinal', in ODNB, vol.1, pp. 824-831.

8. Ginevra CROSIGNANI, Thomas M. McCOOG, Michael QUESTIER (eds.), Recusancy and Conformity in Early Modern England: Manuscript and Printed Sources in Translation, Toronto: Pontifical Institute of Medieval Studies, 2010, pp. 88-89.

9. DUFFY, Fires of Faith, p. 82; MEYER, op. cit., pp. 145-188.

10. DUFFY, 'Allen, William'; Claire CROSS, The Royal Supremacy in the Elizabethan Church, London: George Allen and Unwin, 1969, p. 41.

11. Robert M. KINGDON (ed.), The Execution of Justice in England by William Cecil, and A True, Sincere and Modest Defense of English Catholics by William Allen, Ithaca, New York: Cornell University Press, 1965, pp. 5-7.

12. Ibid., pp. 9-10.

13. Ibid., pp. 20-21.

14. Ibid., p. 37.

15. Ibid., p. 94.

16. Ibid., pp. 94-95.

17. DUFFY, ‘Allen, William'; KINGDON, op. cit, pp. xxxiii - xxxvii, 160, 190.

18. DUFFY, Ibid.

19. The Works of Mr Richard Hooker [...] in eight books of ecclesiastical polity [...], London: Thomas Newcomb for Andrew Crook, 1666, Book VIII, p. 448. 


\section{ABSTRACTS}

Between 1558 and 1570, Protestant and Catholic propagandists debated the claim of the English Church to be a true Church; after the excommunication of Elizabeth, the dispute moved on to whether Catholics were being executed for a political crime or sacrificing their lives for their faith. The irreconcilable positions of the two sides concerning orthodoxy, heresy, and treason form the subject of this essay.

Entre 1558 et 1570, la polémique entre catholiques et protestants portait sur la prétention de l'Église anglaise au statut de véritable Église. Les termes du débat changèrent après l'excommunication d'Élisabeth $\mathrm{I}^{\mathrm{re}}$ : il s'agissait désormais de savoir si les catholiques se faisaient exécuter pour un crime politique ou bien si c'est pour leur religion qu'ils donnaient leur vie. Le présent essai expose les positions irréconciliables des deux camps au sujet de l'orthodoxie, de l'hérésie et de la trahison dans l'Angleterre élisabéthaine.

\section{AUTHOR}

CLAIRE CROSS

University of York 